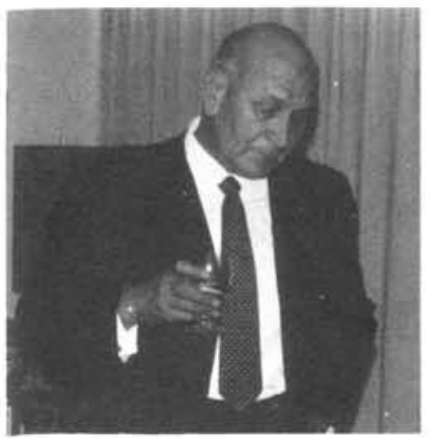

\title{
PLANNING THE 27th INTERNATIONAL GEOLOGICAL CONGRESS
}

by

Aleksandr V. Sidorenko

\begin{abstract}
Academician Aleksandr V. Sidorenko, Chairman of the 27 th International Geological Congress (IGC) and a leading Soviet geologist and science administrator, was killed March 23, 1982, in a car accident while visiting Algeria. His death, announced by the U.S.S.R. official news agency TASS, was acknowledged by Soviet President L.I. Brezhnev and other leaders, indicating the high esteem in which he was held in the U.S.S.R. For the past six years Dr. Sidorenko has been vice-president of the Soviet Academy of Sciences and worked as the Minister of Geology from 1962 to 1975. His early geological work was conducted in the Central Asian Republic of Turkmenia in the 1940s and in the Kola Peninsula of northern Russia in the 1950s. In 1961, he was assigned to Moscow and served briefly as a high-level science coordinator before being moved to the Geology Ministry. In 1966 he was awarded the Lenin Prize, made a full member of the Academy of Science, and appointed an alternate member in the Communist's Party Central Committee. As Chairman of the 27th IGC, he played a pivotal role in setting the framework for the Congress, which is to be held in Moscow in 1984 and expected to attract nearly 6000 scientists worldwide. In this article, submitted to EPISODES shortly before his death, he outlines some of the plans under way for the 27 th IGC.
\end{abstract}

\section{Introduction}

Although the 26 th session of the IGC was held less than two years ago, plans are already progressing for the 27 th IGC, the third International Congress to be held in the U.S.S.R. The two previous Congress meetings were devoted to small areas of the U.S.S.R. - in 1937, to the geology of the European areas of the U.S.S.R., and in 1897 to the Baltic Shield. The 1984 Congress, unlike the previous two meetings, will involve geologists from remote regions of the U.S.S.R.

\section{Structure of the Congress Organizing Committee}

The Congress Organizing Committee (COC), which consists of 84 members, is responsible for the over-all coordination, planning and execution of the Congress. The Committee includes specialists representing different scientific centres as well as executives from ministries and offices engaged in geological studies. During 1981, the Committee met eight times to elect members of the commission, plan the scientific program, field excursions, and the contents of the first circular.

One of the main tasks of the Organizing Committee is to work out a scientific program that not only takes into account the precedents set at previous IGC meetings, but is able to identify geological trends that will become increasingly important in the next four years. In order to overcome the difficulties associated with planning four years in advance, the committee consulted representatives from international scientific associations, such as IUGS, as well as national geological societies.

The first circular, released in February, 1982, includes general information, a preliminary scientific program, and a description of the excursions. The Secretariat of the COC has received about 50 letters from different international scientific organizations, such as the IGCP and ICL, either adopting the committee's suggestions for the present program or commenting on possible changes. It is hoped that the second circular will incorporate comments from these associations. The scientific program now consists of six plenary colloquia, with 22 sessions and 39 intersectional symposia organized along traditional lines for an IGC. Proposed colloquia include Geology of the U.S.S.R., Energy Resources of the World, Palaeogeography of the Oceans, Arctic Geol-

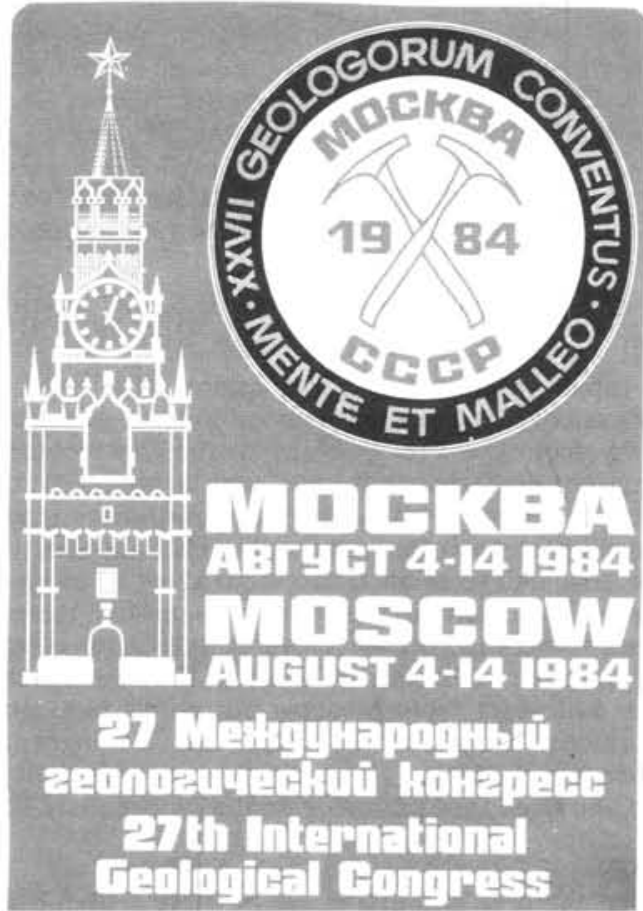

ogy, Tectonics of Asia, and Earthquakes and Hazards Prevention. Major sessions include sections on Stratigraphy, Lithology, Tectonics, Geophysics, Petrology, Mineralogy, Hydrogeology, and Geological Education. The Committee is attempting to overcome the problem of conflicting scheduling of discussions and meetings.

\section{Scientific Excursions}

Because one of the most important parts of the IGC is field excursions, some members of the COC, mainly from the U.S.S.R. Academy of Sciences, and the Ministries of Oil and Geology, have planned 96 excursions. The trips will cover the entire territory of the U.S.S.R., from its western boundaries to the Pacific Ocean and from the Arctic ocean to the high 


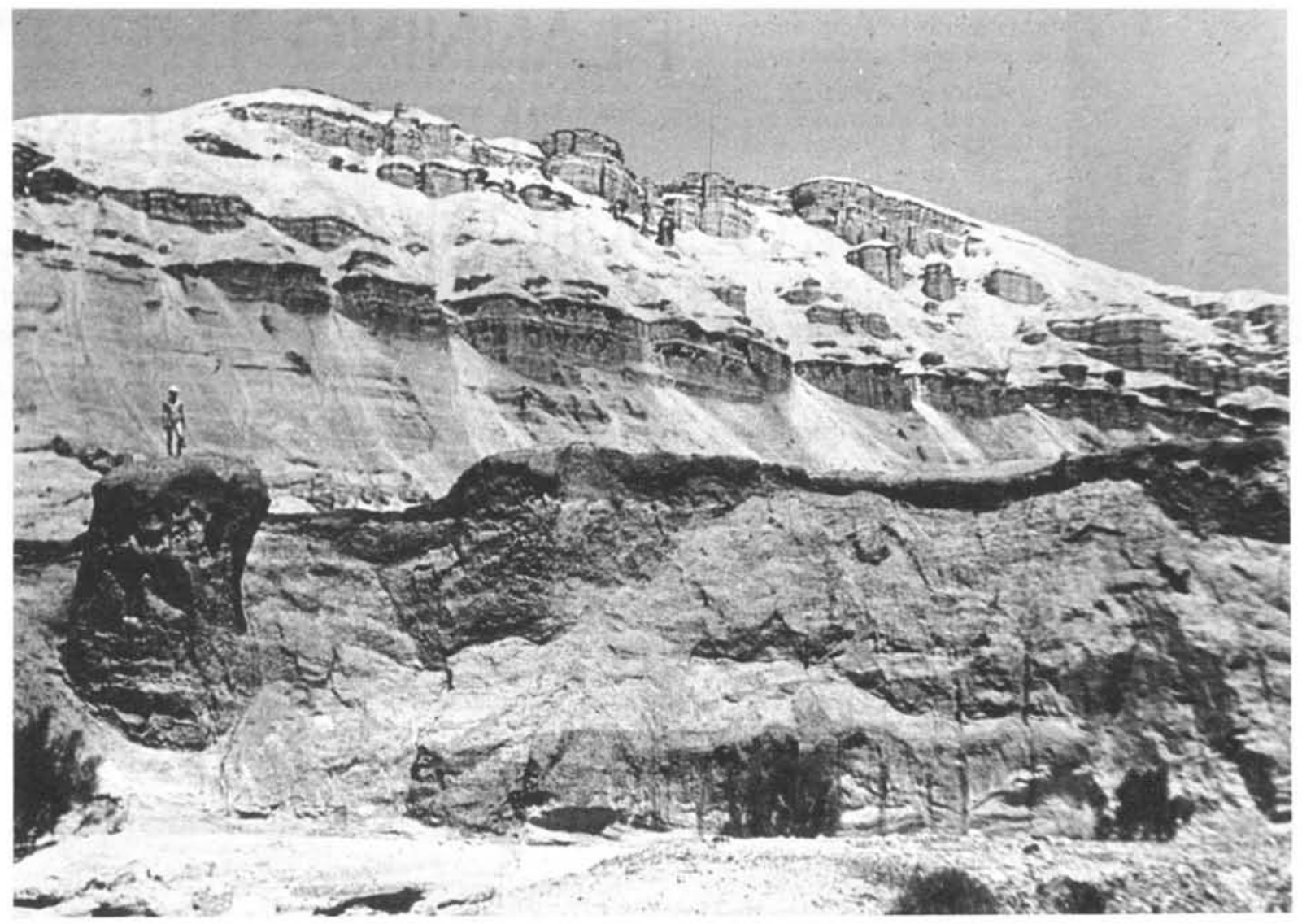

Tertiary section in Jungaria, which will be demonstrated during excursion $033 \mathrm{~A}+\mathrm{C}$

ranges of central Asia - regions of the U.S.S.R. which visitors rarely see.

Proposed topics for the 10-day excursions, which will complement discussions at the conference, include discussions on stratigraphy from the Precambrian to the Quaternary, metamorphism, metallogeny, tectonics and a study of the geological structure of metallic and non-metallic deposits, as well as coal, oil and gas deposits. Participation will be limited to about 40 to allow a thorough study of all geological structures. The Committee has also asked the regional committees to arrange one or two-day scientific symposia on themes that will be discussed during the excursions. All excursions will start from Moscow but participants may join the excursions from such cities as Leningrad, Kiev, Khabarovsk and Irkutsk. Historic tours of ancient Russia, Leningrad and Kiev, are planned for the weekends.

\section{Exhibits}

"GEOEXPO 84" - a scientific and technical exhibition - is scheduled to take place, like the technical sessions, in $\mathrm{V} / \mathrm{O}$ "SOVINCENTR", a $6400 \mathrm{~m}^{2}$ exhibit hall at the All-Union Trade Centre. GEOEXPO 84 will be open not only to research institutions, but also to manufacturers of geological and geophysical equipment. In addition to exhibits, all scientific geological institutions, such as Moscow State University, and paleontological and mineralogical museums are making preparations for special exhibits.

\section{Circulars and Information}

Two others circulars will be available once comments have been received and incorporated from the first one. There are also plans to publish the scientific program, review abstracts and colloquia papers, as well as booklets dedicated to the leading geological institutions in the U.S.S.R.

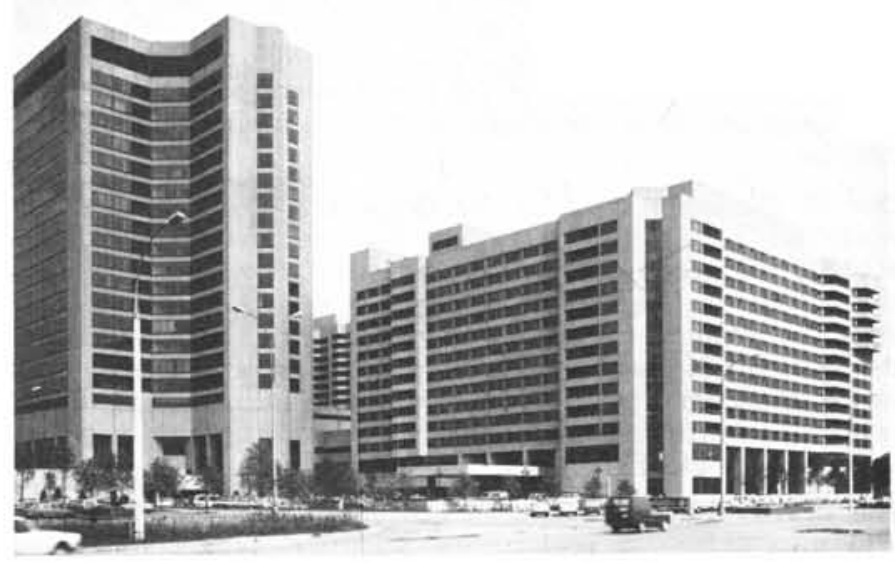

V/O "SOVINCENTR", MOscow, where IGC sessions will be held.

For information contact: Dr. N.A. Bogdanov, General Secretary, Organizing Committee of the 27th International Geological Congress, Staromonetny per. 22, Moscow 109180, U.S.S.R. 